\title{
Direct development in two Myobatrachid Frogs, Arenophryne rotunda Tyler and Myobatrachus gouldii Gray, from Western Australia
}

\author{
Marion Anstis ${ }^{1}$ J. Dale Roberts ${ }^{2}$, and Ronald Altig \\ 126 Wideview Rd., Berowra Heights, NSW 2082, Australia. Email: frogpoleatpg.com.au \\ 'School of Animal Biology (M092), University of Western Australia, \\ 35 Stirling Highway, Crawley, Western Australia 6009 Australia \\ ${ }^{3}$ Department of Biological Sciences, Mississippi State University, Mississippi State, MS 39762 USA
}

\begin{abstract}
The closely related Western Australian myobatrachid frogs Arenophryne rotunda and Myobatrachus gouldii deposit eggs in burrows that are dug by the adults in moist sand. Embryonic development requires up to two months and is completed entirely within the jelly capsule. The developmental stages of these two taxa are described and compared with those of the South American direct developing leptodactylid frog Eleutherodactylus coqui.
\end{abstract}

Key words: Australia, direct development, embryo, endotrophic, myobatrachid

\section{INTRODUCTION}

The frogs Arenophryne rotunda and Myobatrachus gouldii (Myobatrachidae) are widely distributed in semi-arid and arid regions of southwestern Australia (Tyler et al. 2000). Both species are forwards burrowers that oviposit deep underground in moist sand where embryos undergo direct development, an endotrophic breeding mode in which all embryonic development through to a froglet takes place within the jelly layers of the egg (Altig and Johnson 1989). Arenophryne rotunda calls from July-November (austral winter to spring). Pairs of males and gravid females not in amplexus have been found together in November at a mean depth of $45 \mathrm{~cm}$, and in February and April (late summer to autumn) at mean depths of $75-78 \mathrm{~cm}$, but eggs were only found in April (Roberts 1984). Myobatrachus gouldii calls from September-February (spring to late summer); a male and female burrow together, not in amplexus, into deep, moist sand where they appear to remain together until autumn when they deposit eggs at depths of $80-115 \mathrm{~cm}$ (Roberts 1981, 1984). Tyler's (1976a) suggestion of a close relationship between these two species and with Metacrinia was supported by Maxson and Roberts (1985), Read et al. (2001) and the recent analysis by frost et al. (2006).

Direct development in amphibians has evolved in at least seventeen genera from nine families of anurans worldwide (Thibaudeau and Altig 1999). Although the life histories of a number of these species have been described, especially for the genus Eleutherodactylus (e.g. Gitlin 1944; Jameson
1950; Wake 1978; Townsend and Stewart 1985), there are no available descriptions of the Australian species which include the myobatrachid genera Arenophryne, Myobatrachus and Metacrinia and the microhylid genera Austrochaperina and Cophixalus.

The South American leptodactylid genus Eleutherodactylus consists of several direct developing species and the field staging system developed for E. coqui by Townsend and Stewart (1985) is the most comprehensive system available for this breeding mode. We describe some preserved embryonic material in the Western Australian Museum of $A$. rotunda and $M$. gouldii and compare them to E. coqui (see Table 3 and Discussion). Brief comparisons to Australian direct developing microhylids and also to species from other Australian endotrophic guilds including the nidicolous, paraviviparous and exoviviparous species are made where relevant. These are not direct developers because they have a hatched tadpole stage (sensu Altig and Johnston 1989), but have some similar characteristics to $A$. rotunda and M. gouldii in early stages.

\section{MATERIALS AND METHODS}

Fifteen embryos of $A$. rotunda from four clutches collected near Shark Bay, WA and reared in the laboratory in April 1981 by J. D. Roberts, were preserved at irregular intervals in Tyler's fixative (Tyler 1962) and transferred to $70 \%$ ethanol when accessioned into the West Australian Museum: WAM R97047-50, 97053, 97057, R97059-60 (see 
A

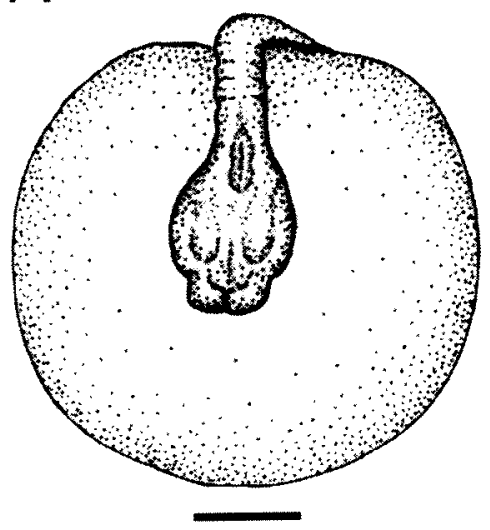

C
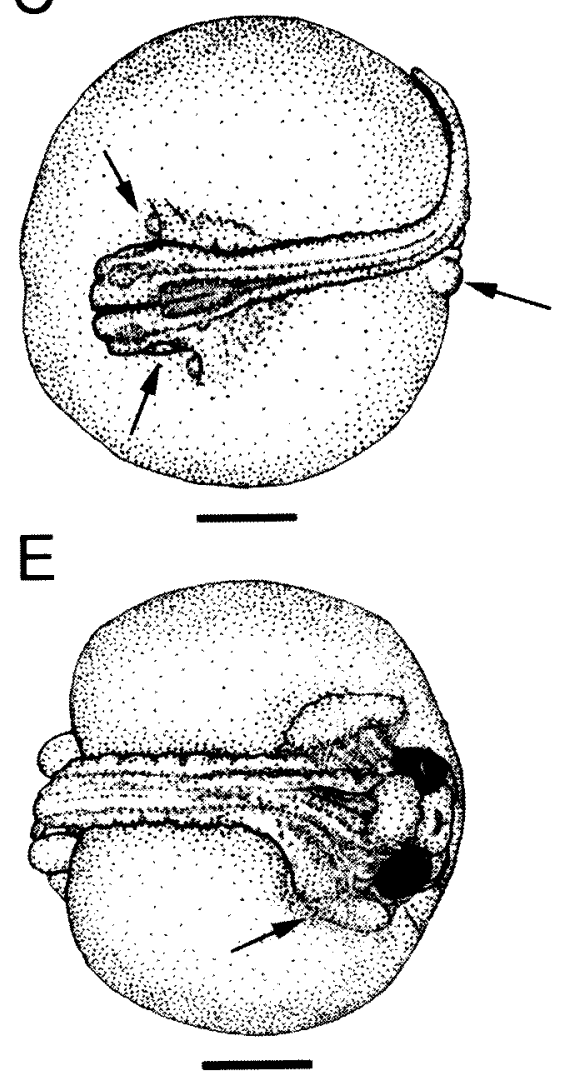

B

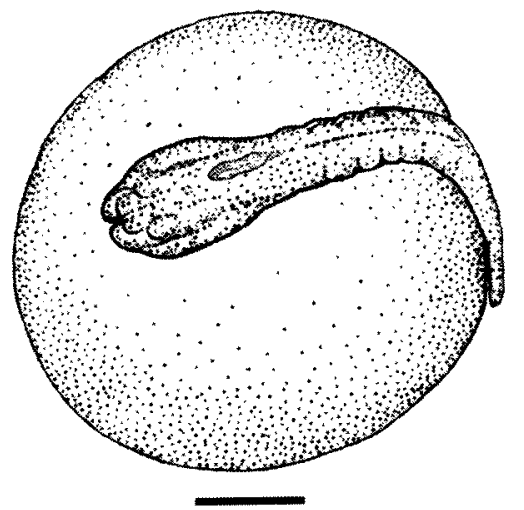

D

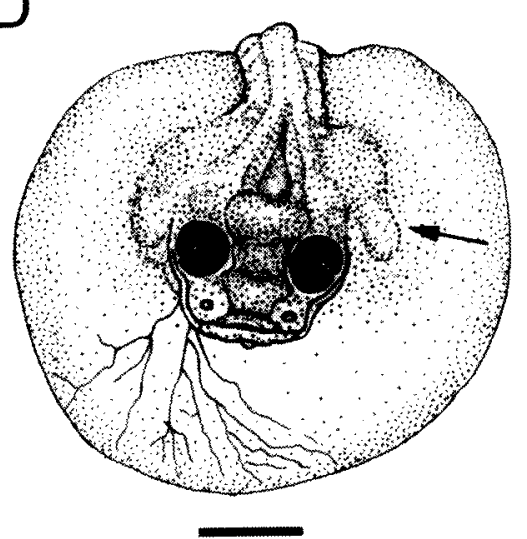

F

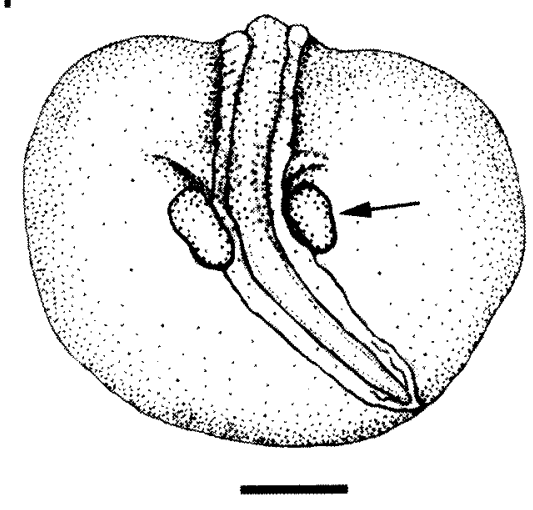

Figure 1 Stages 3, 4 and 6 (Townsend and Stewart, 1985) of Arenophryne rotunda. A and B = stage 3, anterior and lateral view; $C=$ stage 4 , dorsal view; $D, E$ and $F=$ stage 6 , anterior, dorsal and posterior views. Scale bar represents $1 \mathrm{~mm}$. Arrows indicate features highlighted in bold in Table 1.

Appendix 1). Nine embryos up to stage 13 of Townsend and Stewart (T\&S; 1985) from one clutch of $M$. gouldii were collected $15 \mathrm{~km}$ north-east of Perth, WA, then reared and preserved at irregular intervals: WAM R97036-40. Six individuals just prior to hatching and recently hatched from four marked nests in the field were preserved after being excavated in April 1982: WAM R97041-42, 97044-45 (see Appendix 2). All embryos were reared in total darkness at ambient room temperatures in the laboratory which were lowered slightly (approximately $17-20^{\circ} \mathrm{C}$ ) to better simulate cooling conditions at the nest sites in the field.
Measurements were taken with an ocular micrometer attached to a Wild M5 stereoscopic microscope and drawings were prepared with the aid of a camera lucida. The photograph (Figure 4F) was taken with a Nikon D70 digital SLR camera and $60 \mathrm{~mm}$ micro lens. Embryos were staged using the system of Townsend and Stewart (1985) which was devised for the direct developing leptodactylid E. coqui, with additional references to toe development based on the staging table for aquatic larvae of Gosner (1960). For the sake of completeness, descriptive observations on egg clutches provided for $A$. rotunda and $M$. gouldii by 

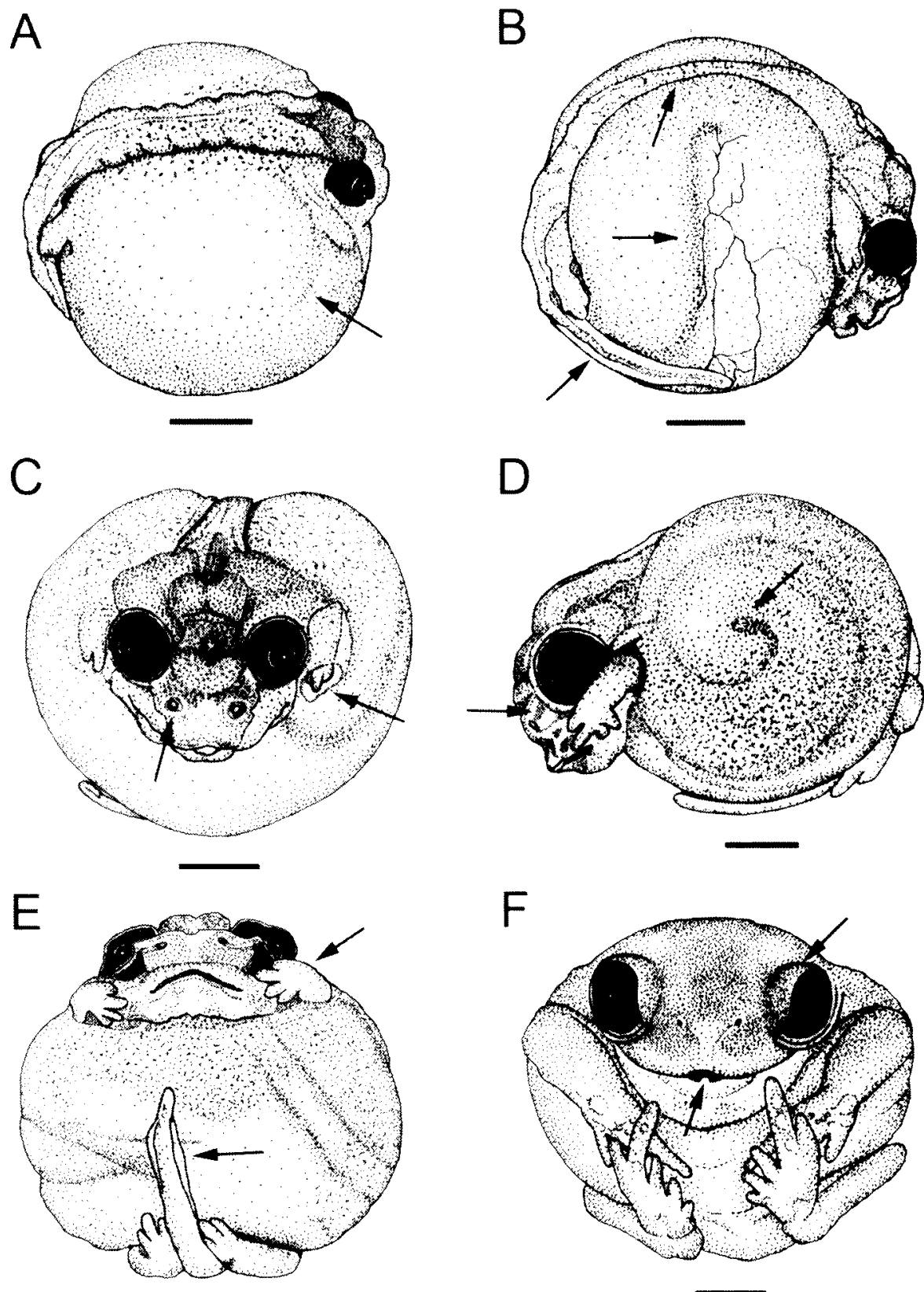

Figure 2 Stages 6,7,9, and 15 (Townsend and Stewart, 1985) of Arenophryne rotunda. A = stage 6, dorsolateral view, $B$ and $C=$ stage 7 , lateral and anterior views; $D$ and $E=$ stage 9 , lateral and ventral views; and $F=$ stage 15 , just prior to hatching, ventral view. Scale bar represents $1 \mathrm{~mm}$. Arrows indicate features highlighted in bold in Table 1.

Roberts (1984 and 1981, respectively) are summarised prior to the descriptions for each species, with additional notes on development (Roberts, unpubl data). Embryos in stages 1, 2, 3-7, 9-11, 13 and 15 are described and most stages are illustrated (Figures 1-4). Brief observations were made on live embryos during early cell division. The partial deterioration of the youngest preserved embryos of $A$. rotunda (stages 1 and 2 ), and specimens of $M$. gouldii at stages 11 and 13, limited their descriptions.

\section{Results}

The two species have various morphological characteristics in common. Both have a generally similar parallel progression through the developmental stages described in Tables 1 and 2 . Measurements of embryos for each species are given in the Appendices and Table 3 summarises key differences between the Australian species and E. coqui.

\section{Development of Arenophryne rotunda}

Clutch sizes of fertilised eggs ranged from 4-11 (mean $7, \mathrm{n}=5$ ). Ovarian development commences in spring (late August), but ovum maturation is not completed until late summer. Three females collected in February 1981 contained 8, 8 and 4 pale 
Table 1 Development of Arenophryne rotunda. T\&S = Townsend and Stewart (1985) stages. Figure numbers in parenthesis. Features indicated by arrows in Figures 1 and 2 are highlighted in bold.

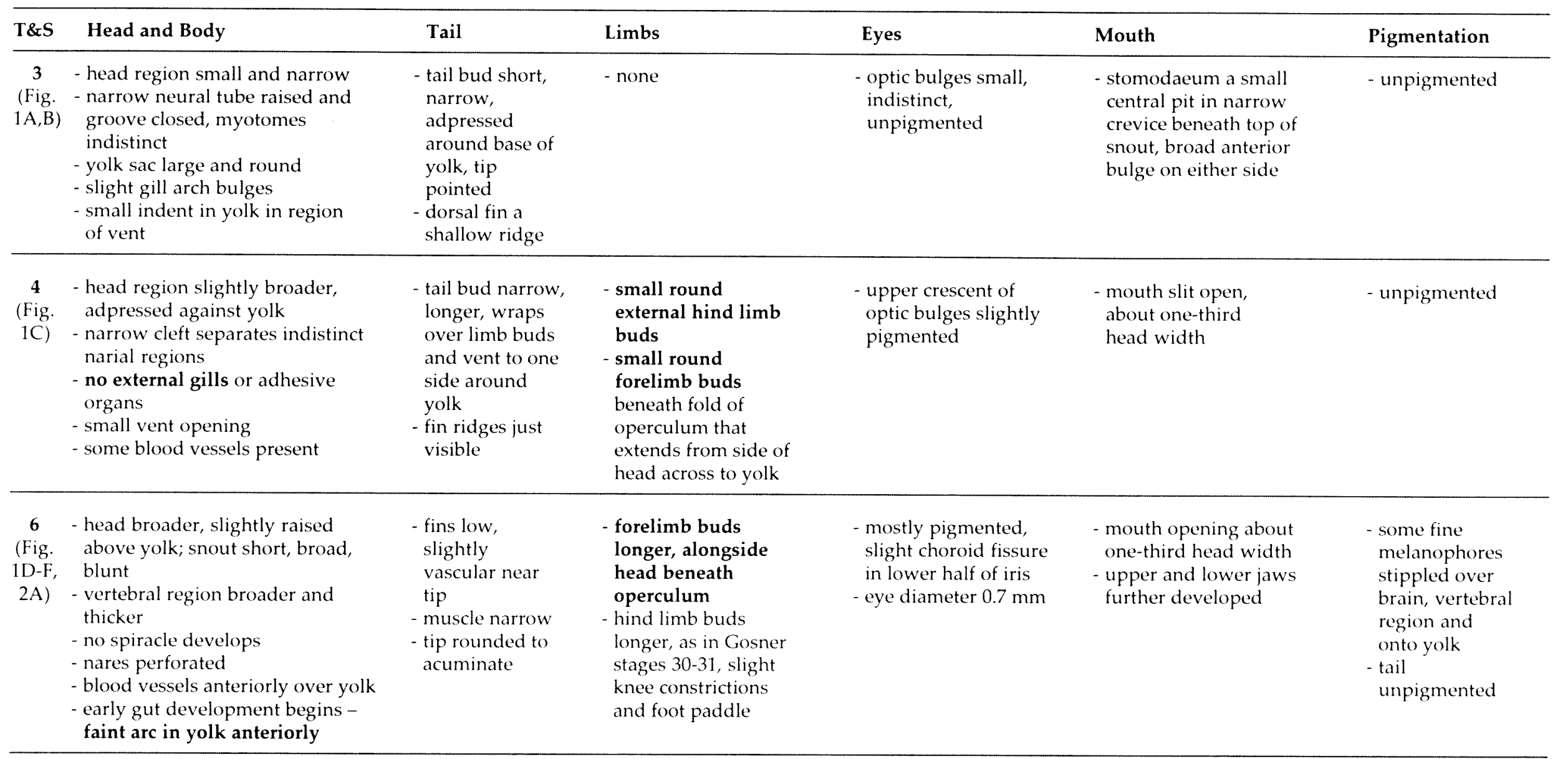


7 - body broadens slightly

(Fig. - vertebral region flatter and

2B-D) recessed within yolk (Fig. 2C)

no external gills develop

- internal flap inside naris

- first gut wall in each side of

yolk; vitelline blood vessels

increased

- groove down either side of

vertebral region

9 - head well defined and prominent,

(Fig, snout broadly truncate, chin

2D,E) raised above yolk

- vertebral myotomes more defined

nares oval, diameter $0.1 \mathrm{~mm}$,

directed anteroventrally, internal

flap more distinct; lacrimal

groove from naris to eye

(Fig. 2D)

vent bordered by narrow rim

thick, spiral yolk-filled coil

in gut

15 - head and body fully defined

(Fig. - intestinal coil thick, yolk-filled,

2F) partly visible through

epidermis, not yet

differentiated into digestive

system of adult

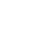

tail longer, - limbs lengthen,

tightly slight indent on

adpressed each side of foot

around yolk

extends to

about midway

around yolk

paddle as for

Gosner stage 33

left forelimb partly

protrudes through

operculum (Fig. 2C)
- diameter noticeably

increased to

$1.14 \mathrm{~mm}$

- fully pigmented.

choroid fissure

closed

denser over

head, vertebral

recion and

down sides

of yolk tail remains

\section{narrow,}

extends two-

thirds around

yolk

- tip narrow

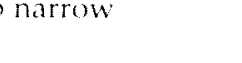

\section{forelimbs}

completely erupted

through operculum

hind limbs longer

with distinct knee

joints, toes with 5

digits discernable,

as for Gosner

stage 36
- eyes lateral,

prominent, diameter

$1.3 \mathrm{~mm}$
- mouth about half

head width

- small, conical

structure begins to

project upwards on

inside centre of lower

lip, corresponding

notch above in

upper lip entire dorsum and sides of

yolk uniform

light brown

tail

unpigmented

fully resor bed

- limbs fully

developed, forearms

more robust than

- eyes large, eyelids

and nictitating

- mouth extends to

membrane formed

hindlimbs

below each eye

fully formed, fits

into notch in upper

lip (now deeper

posteriorly) when

mouth closes 
Table 2 Development of Myobatrachus gouldii. T\&S = Townsend and Stewart (1985) stages. Figure numbers in parenthesis. Features indicated by arrows in Figures 1 and 2 are highlighted in bold.

\begin{tabular}{|c|c|c|c|c|c|c|}
\hline$T \& S$ & Head and Body & Tail & Limbs & Eyes & Mouth & Pigmentation \\
\hline $\begin{array}{c}5 \\
(\mathrm{Fig} . \\
3 \mathrm{~A}-\mathrm{C})\end{array}$ & $\begin{array}{l}\text { - head and snout fairly broad, } \\
\text { adpressed against yolk } \\
\text { - vertebral region narrow, raised } \\
\text { above yolk } \\
\text { - yolk large and round, some } \\
\text { blood vessels anteriorly } \\
\text { - gill arch bulges, no external gills } \\
\text { - no adhesive organs } \\
\text { - nares perforated, widely spaced } \\
\text { - small medial vent beneath base } \\
\text { of tail, rim around opening }\end{array}$ & $\begin{array}{l}\text { - well advanced, } \\
\text { extends almost } \\
\text { halfway around } \\
\text { yolk } \\
\text { - fins low at base of } \\
\text { body, broaden } \\
\text { towards tip } \\
\text { - tip broadly } \\
\text { rounded, } \\
\text { vascular }\end{array}$ & $\begin{array}{l}\text { - small, round to } \\
\text { ovoid external } \\
\text { hind limb buds } \\
\text { - small round } \\
\text { forelimb buds } \\
\text { mostly covered } \\
\text { by opercular } \\
\text { fold extending } \\
\text { from each side of } \\
\text { head (Fig. 3B) }\end{array}$ & $\begin{array}{l}\text { - iris mostly } \\
\text { pigmented } \\
\text { around } \\
\text { outer third } \\
\text { - narrow } \\
\text { choroid } \\
\text { fissure }\end{array}$ & $\begin{array}{l}\text { - mouth slit open, one- } \\
\text { third head width }\end{array}$ & $\begin{array}{l}\text { - few fine } \\
\text { melanophores } \\
\text { scattered over } \\
\text { brain and } \\
\text { vertebral region } \\
\text { to base of body }\end{array}$ \\
\hline $\begin{array}{c}6 \\
\text { (Fig. } \\
\text { 3D,E) }\end{array}$ & $\begin{array}{l}\text { - head larger, broader, chin slightly } \\
\text { raised above yolk } \\
\text { - snout short, broad, truncate } \\
\text { - vertebral region broad, recessed } \\
\text { into yolk } \\
\text { - nares deeper, no spiracle } \\
\text { - yolk slightly expanded, first gut } \\
\text { coil begins } \\
\text { - vitelline blood vessels increased }\end{array}$ & $\begin{array}{l}\text { - tail as for stage } 5 \\
\text { in single specimen } \\
\text { observed }\end{array}$ & $\begin{array}{l}\text { - hind limb buds broad, } \\
\text { longer, as in Gosner } \\
\text { stage } 30 \\
\text { - forelimb buds } \\
\text { longer, beneath } \\
\text { operculum } \\
\text { alongside head }\end{array}$ & $\begin{array}{l}\text { - almost } \\
\text { fully } \\
\text { pigmented } \\
\text { - choroid } \\
\text { fissure } \\
\text { narrow } \\
\text { - diameter } \\
0.8 \mathrm{~mm}\end{array}$ & $\begin{array}{l}\text { - mouth opening } \\
\text { slightly more than } \\
\text { one-third head width } \\
\text { - upper and lower jaws } \\
\text { defined }\end{array}$ & $\begin{array}{l}\text { - dorsal pigment } \\
\text { increased over } \\
\text { head, vertebral } \\
\text { region and partly } \\
\text { onto yolk } \\
\text { - tail unpigmented }\end{array}$ \\
\hline $\begin{array}{c}9 \\
(\text { Fig. } \\
3 \mathrm{~F} \\
4 \mathrm{~A})\end{array}$ & $\begin{array}{l}\text { - head broad, frog-like } \\
\text { - snout short, broad and truncate, } \\
\text { directed anteroventrally } \\
\text { - body slightly broader } \\
\text { - vertebral region broader, slightly } \\
\text { raised, shallow groove down } \\
\text { either side and down centre, } \\
\text { myotomes visible (Fig. 3F) } \\
\text { - nares oval, anterior, rim present, } \\
\text { internal flap extends downwards } \\
\text { - thick spiral intestinal coil }\end{array}$ & $\begin{array}{l}\text { - tail full length, } \\
\text { extends to } \\
\text { beneath head } \\
\text { - fins broader } \\
\text { towards tip } \\
\text { - muscle broad at } \\
\text { base, flat against } \\
\text { body, begins to } \\
\text { taper from mid- } \\
\text { length to tip }\end{array}$ & $\begin{array}{l}\text { - hind limbs } \\
\text { adpressed } \\
\text { ventrally around } \\
\text { yolk, } 5 \text { toe digits } \\
\text { as for Gosner } \\
\text { stage } 35 \\
\text { - forelimbs longer, } \\
\text { alongside head, } \\
\text { fingers visible } \\
\text { beneath operculum } \\
\text { (Fig. } 4 \mathrm{~A} \text { ) }\end{array}$ & $\begin{array}{l}\text { - eyes lateral } \\
\text { - choroid } \\
\text { fissure } \\
\text { closed } \\
\text { - diameter } \\
1.2 \mathrm{~mm}\end{array}$ & $\begin{array}{l}\text { - small, conical } \\
\text { structure (visible } \\
\text { when mouth opened), } \\
\text { begins to project } \\
\text { upwards from inside } \\
\text { centre of lower lip; } \\
\text { small corresponding } \\
\text { notch above in } \\
\text { upper lip }\end{array}$ & $\begin{array}{l}\text { - dorsum uniform } \\
\text { brown over brain, } \\
\text { vertebral region; } \\
\text { less dense over } \\
\text { yolk to midway } \\
\text { down sides } \\
\text { of body } \\
\text { - limbs partly } \\
\text { pigmented } \\
\text { - tail unpigmented }\end{array}$ \\
\hline
\end{tabular}


10 - herd broad well defined

(Fig. more frog-like

$4 B, C$ - diameter of nares $0.16 \mathrm{~mm}$, distinct lacrimal groove from

each naris to each eve

thick spiral coil in gut, visible through epidermis tail extends to forearm in one specimen

muscle slightly

translucent down

centre of posterior

halt hind limbs longer toes as for Gosner stage 37 , shorter

than fingers

both forearm

completely

erupted through

skin, robust trees

prominent

- diameter

$1.2 \mathrm{~mm}$

mouth opening about

half head width

conical structure

further developed

nonkeratinised uniform brown,

darker over hear

and vertebral

- sides of body

lightly pigmented to partway

across venter

- limbs lightly

pigmented, mainly

over upper half

tail unpigmented

\begin{tabular}{lcc}
\hline $11-$ specimen dead prior to & - tail almost full & - toes as for Gosner \\
preservation, misshapen & length of body & stage 38, to about \\
- vertebral myatomes quite distinct & half length at \\
& & hatching
\end{tabular}

dorsum uniform

brown, lighter

brown over limbe

and sides

- mid-ventral

rexion remains

unpigmented

13 - head broadens further

tail regresses to

- limbs fully

(Fig. - snout very short and blunt

4D) - body appears fully formed, but dead prior to preservation.

around side of similar to about

body

similar to about
Gosner stage 43

partly misthapen

muscular ridge

- subarticular

clearly defined tubercles present

tip still broadly

rounded

- dorsum uniform

dark brown,

slightly lighter

over limbs and

sides of body

throat and chest

stippled with

brown ventrally

creamy yellow of

yolk visiblo

ventrally

tail unpigmented

but for a few dark

specks anteriorly

over muscle

15 - head and body fully defined
(Fig. as a minature of adult
$4 \mathrm{E}, \mathrm{F})$-intestinal coil still yolk-filled,
partly visible through epiderm
not yet differentiated into
digestive system of adult
- nares very small, diameter
0.08 mm, opening further
obscured by internal flap

tail fully resorbed

limbs full

developed

forearms more

robust than

hindlimbs

ike those

if adult

eyelid,

nictitating

membrane

present

bscured by internal flap

mouth extends to

below each cye,

tongue visible

into notch in upper

lip (now deeper

posteriorly) when

mouth closes

\section{entire dorsum}

and limbs

uniform dark

brown

entire venter and

undersurface of

limbs stippled

brown, darker

ver throat

- soles of feet

darker 
Table 3 Differences between available preserved stages of $A$. rotunda and $M$. gouldii and those of similar live stages for E. coqui. As no observations of behaviour or ECD (endolymphatic calcium deposits, visible in life) were available for the Australian genera, these are not included here for $E$. coqui. Stages prior to stage 4 and features which are the same for each are excluded. T\&S = Townsend and Stewart stages (1985).

\begin{tabular}{|c|c|c|}
\hline T\&S & Eleutherodactylus & Arenophryne and Myobatrachus \\
\hline 4 & $\begin{array}{l}\text { - eye bulges distinct } \\
\text { - gill arches present, but no gills present } \\
\text { - tail bud first apparent }\end{array}$ & $\begin{array}{l}\text { - eye bulges discernable } \\
\text { - slight gill arches } \\
\text { - tail bud elongates enough to bend around yolk to one side }\end{array}$ \\
\hline 5 & $\begin{array}{l}\text { - forelimbs round to ovoid, external } \\
\text { - eyes prominent, unpigmented } \\
\text { - gill buds first appear from gill arches, gill circulation } \\
\text { - tail bud elongates enough to bend, small thin fin }\end{array}$ & $\begin{array}{l}\text { - forelimb buds beneath operculum } \\
\text { - eyes partly pigmented } \\
\text { - indistinct gill arches, no gills } \\
\text { - tail long (especially Myobatrachus), wraps around } \\
\text { yolk, fins well developed and vascular (Myobatrachus), }\end{array}$ \\
\hline 6 & $\begin{array}{l}\text { - forelimbs develop externally } \\
\text { - eye distinct from rest of head, pupil clear } \\
\text { - gills well developed } \\
\text { - tail over one-half final length, small, } \\
\text { membranous fin } \\
\text { - widely scattered melanophores over dorsum }\end{array}$ & $\begin{array}{l}\text { - forelimbs develop beneath operculum } \\
\text { - eye pigment well developed, slight choroid fissure } \\
\text { - no external gills develop } \\
\text { - fins low, poorly developed, slightly vascular } \\
\text { (Arenophryne), or well developed and more } \\
\text { vascular (Myobatrachus) } \\
\text { - some fine melanophore stippling over brain } \\
\text { and vertebral region }\end{array}$ \\
\hline 7 & 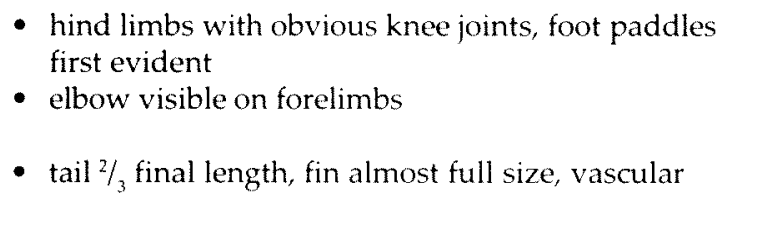 & $\begin{array}{l}\text { - foot develops up to } 3 \text { early toe nubs } \\
\text { - one forelimb begins to break through operculum } \\
\text { (Arenophryne) } \\
\text { - tail at full length, fins remain low (Arenophryne) } \\
\text { beginning of first gut wall within yolk }\end{array}$ \\
\hline 9 & $\begin{array}{l}\text { - tail } 2 / 3 \text { full length with full size fin } \\
\text { - pigmentation expands to about midway down yolk }\end{array}$ & $\begin{array}{l}\text { - forelimbs fully erupted in Arenophryne; still beneath } \\
\text { operculum alongside head in Myobatrachus; toe digits } \\
\text { similar to Gosner stages } 35-36 \\
\text { - tail full length in both } \\
\text { - pigmentation expands around sides and partly } \\
\text { over venter } \\
\text { - beginning of small, conical projection on inside centre } \\
\text { of lower lip, small notch in centre of upper lip }\end{array}$ \\
\hline 10 & $\begin{array}{l}\text { - toes to } 1 / 3 \text { of hatching length } \\
\text { - pigmentation dense on dorsum, less on head }\end{array}$ & $\begin{array}{l}\text { - forelimbs now erupted in Myobatrachus; toes all } \\
\text { individually separate and a bit longer, similar to } \\
\text { Gosner stage } 37 \\
\text { - pigmentation uniform over entire dorsum and sides, } \\
\text { denser over head and vertebral region }\end{array}$ \\
\hline $11-12$ & $\begin{array}{l}\text { - tail full length with full fin } \\
\text { - egg tooth first develops on upper lip by late stage } 12\end{array}$ & $\begin{array}{l}\text { - tail at full length from stage } 9 \\
\text { - nonkeratinised conical projection on inside lower lip }\end{array}$ \\
\hline 13 & $\begin{array}{l}\text { - toes full length, toe pads first evident } \\
\text { - egg tooth develops keratin } \\
\text { - yolk reserve still large }\end{array}$ & $\begin{array}{l}\text { - limbs well advanced, subarticular tubercles develop on } \\
\text { hands and feet, no toe pads } \\
\text { - no egg tooth, nonkeratinised conical projection fits into } \\
\text { deeper notch in upper lip when mouth closes } \\
\text { - intestinal development now obscured by pigment }\end{array}$ \\
\hline 15 & - tail remnant half or less of full length at hatching & - no tail remnant prior to hatching \\
\hline
\end{tabular}

yellow, mature ovarian eggs with a mean diameter of $4 \mathrm{~mm}$. An adult male found on 1 April 1981 was sitting on a clutch of seven eggs buried in sand at a depth of $80 \mathrm{~cm}$ and soil temperature in the nest site at $0845 \mathrm{hr}$ was $25^{\circ} \mathrm{C}$. It was not possible to determine if there was a burrow leading to the frog and eggs, or a chamber around them, as the sand caved in during excavation. The eggs in stage 1 had a mean capsule diameter of $5.5 \mathrm{~mm}(5.0-6.0 \mathrm{~mm})$ and initially adhered together in a cluster by means of the sticky outer surface of each capsule. As they became covered in sand, individual capsules separated. Another clutch at the same depth was unattended by an adult (Roberts 1984). 

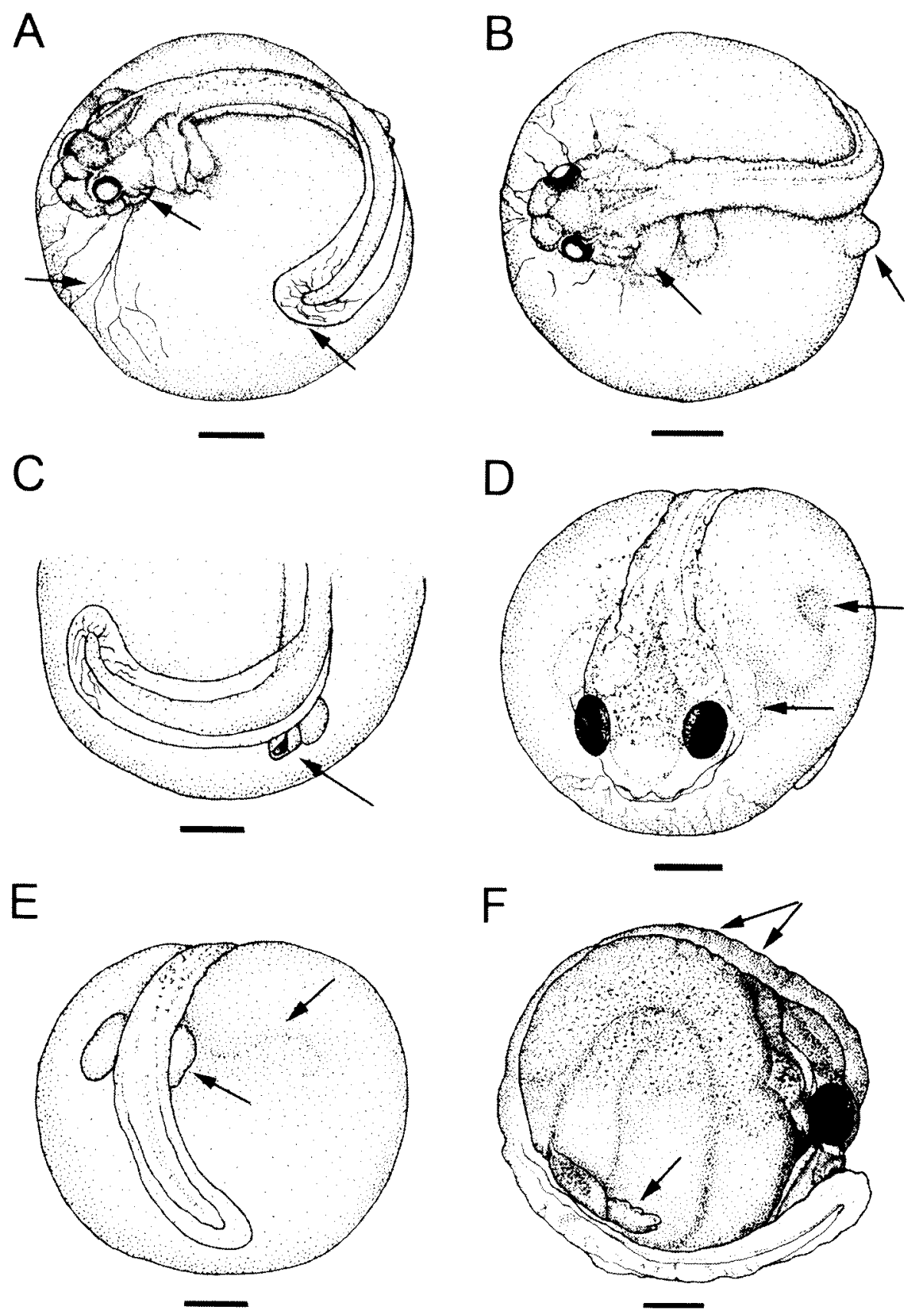

Figure 3 Stages 5,6, and 9 (Townsend and Stewart, 1985) of Myobatrachus gouldii. $\mathrm{A}=$ stage 5, dorsal view; $\mathrm{B}$ and $\mathrm{C}=$ stage 5, dorsal and partial posterior views (line indicates forelimb beneath operculum in $B$ and vent in $C$ ); $D$ and $E=$ stage 6 , anterior and posterior views; and $F=$ stage 9, lateral view. Scale bar represents $1 \mathrm{~mm}$. Arrows indicate features highlighted in bold in Table 2 .

Embryos at stages 1, 2-4, 6, 7, 9 and 15 are described in Table 1, and illustrated in Figures 1 and 2. Embryos are unpigmented during stages 1-4. Live embryos were not easily studied due to fine sand over the capsules. A pair of frogs collected on 1 April 1981, laid 11 eggs (clutch 4) some time between 1-3 April and cleavage furrows were observed during early to mid-cleavage on 4 April. Gastrulation and blastopore formation seemed typical of those described for aquatic tadpoles (Gosner 1960) and the dorsal lip was a distinct indentation. Estimating 2 April as the approximate date eggs were laid, late gastrula was reached after about 5 days and the neural plate began to form (stage 2) after about 10 days. Stage 5 was reached after about 16 days (none preserved) and stage 6 after 24 days.

\section{Hatching and embryonic life span}

Well formed froglets from clutch 4 were observed twitching within the capsules from about 45 days after the eggs were laid, and after about 50 days some were unhatched and adpressed tightly against the capsule wall with no yolk remaining. The last 

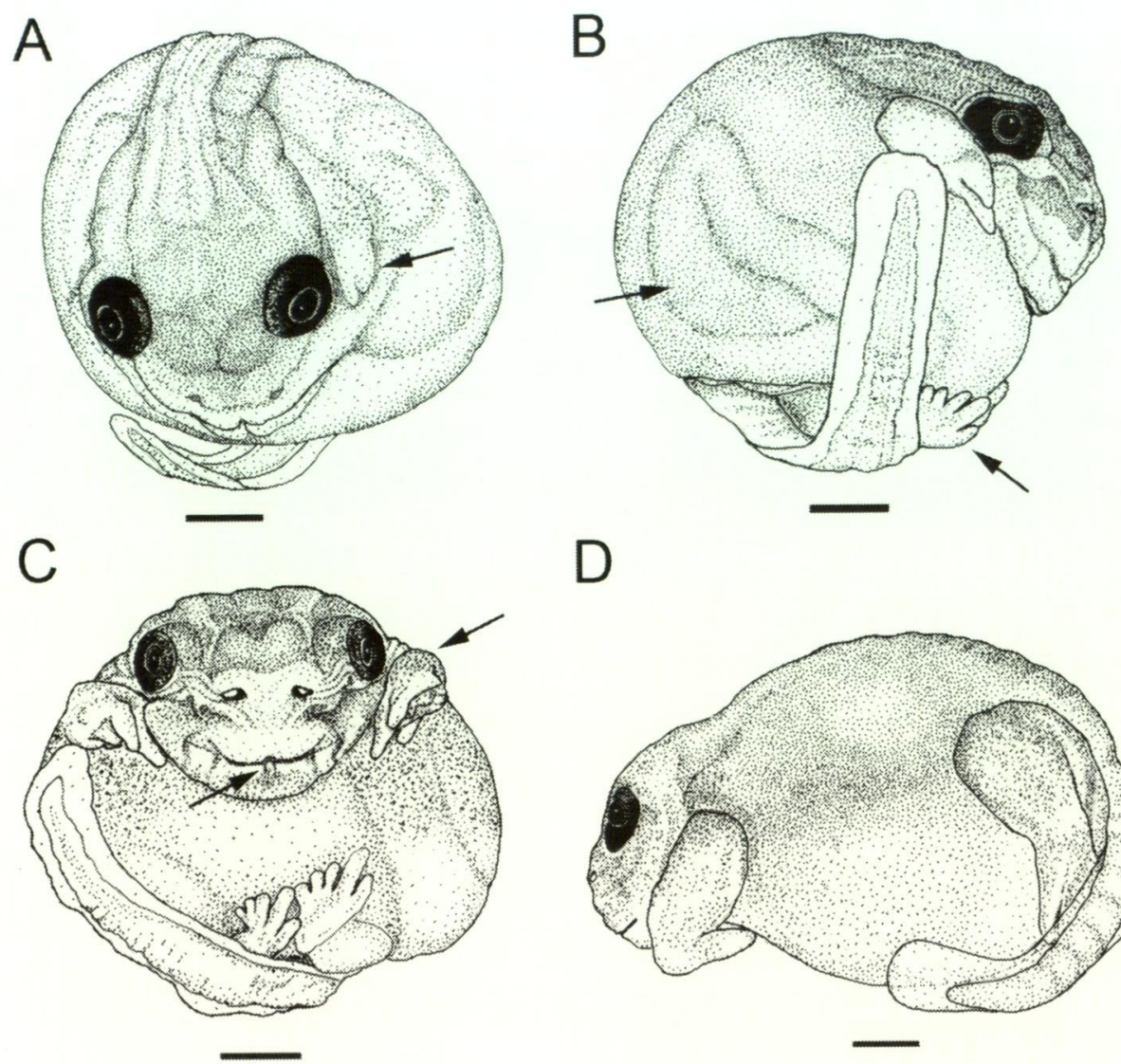

D
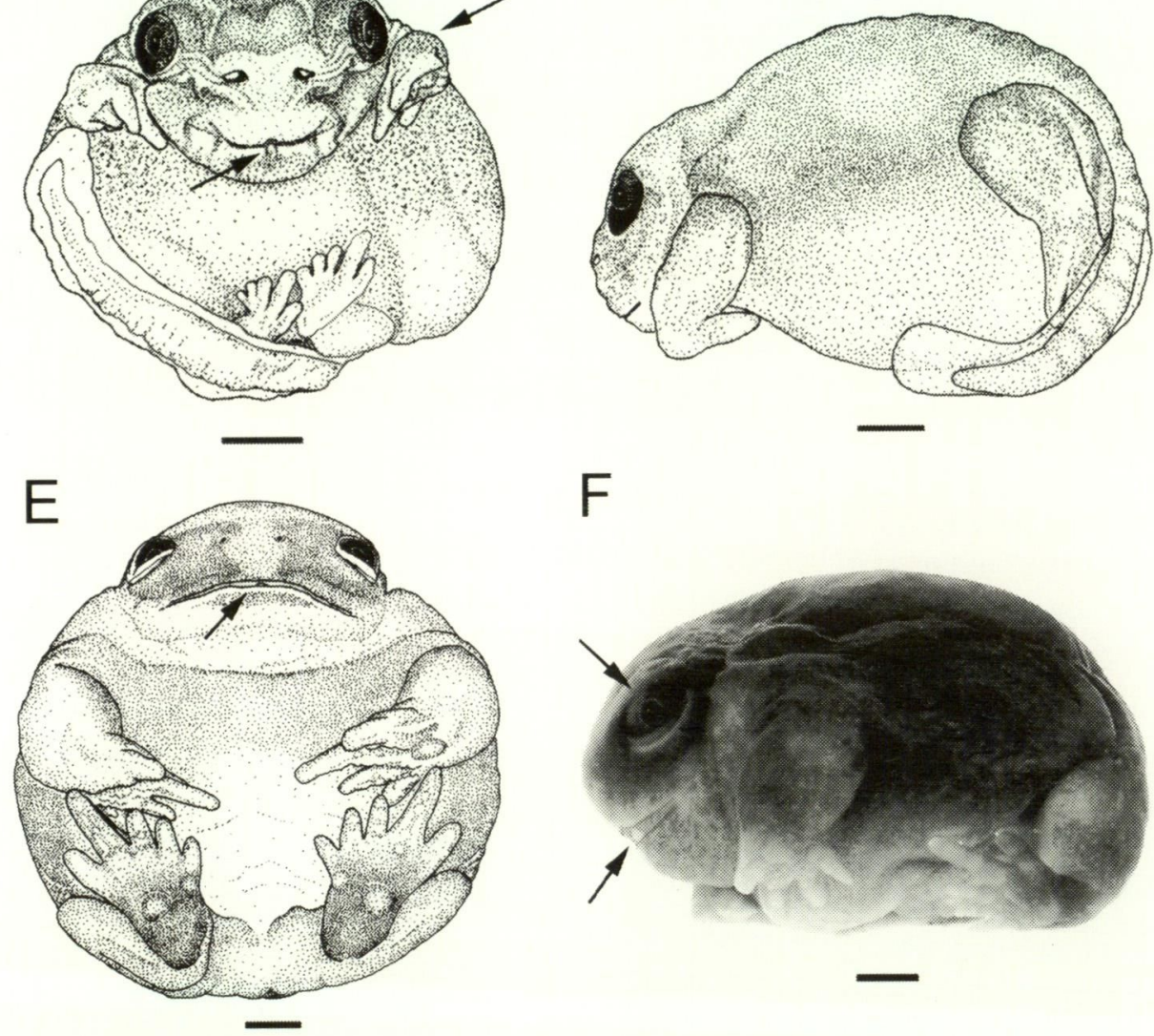

$\mathrm{F}$

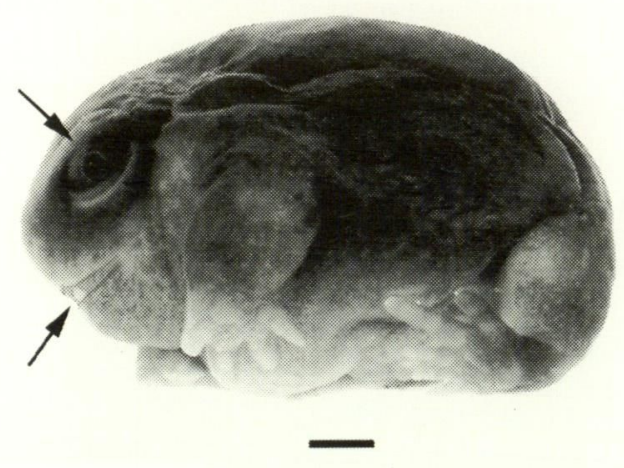

Figure 4 Stages 9, 10, 13 and 15 (Townsend and Stewart, 1985) of Myobatrachus gouldii. A = stage 9, anterior view, forelimb beneath operculum; $\mathrm{B}$ and $\mathrm{C}=$ stage 10 , lateral and ventral views; $\mathrm{D}=$ stage 13 , lateral view; and $\mathrm{E}$ and $\mathrm{F}=$ stage 15 , ventral view and photograph of lateral view, just prior to hatching. Scale bar represents 1 $\mathrm{mm}$. Arrows indicate features highlighted in bold in Table 2.

froglet hatched (yolk present in intestinal loops) on 12 June 1981, about 64 days after the eggs were laid $(\mathrm{SV}=10.4 \mathrm{~mm}$, weight $0.22 \mathrm{~g})$. On 5 June, one froglet from another clutch which had been collected at stage 1 (dorsal lip to mid-gastrula) on 1 April, was found beginning to hatch with one hind limb extended through the capsule wall. When removed and washed to remove sand, the remaining jelly layers came free and the froglet became active and soon began to burrow ( $\mathrm{SV}=9.9$ $\mathrm{mm}$, weight $0.24 \mathrm{~g}$ ). There was a distinct middorsal stripe and the remnant yolk mass was quite large.
Minimum embryonic life span for this individual was about 65 days (estimating four days from fertilisation to mid-gastrula). Three recent hatchlings 1-2 weeks old measured $11.2-11.4 \mathrm{~mm}$ (mean $11.3 \mathrm{~mm}$ ) and all weighed $0.25 \mathrm{~g}$.

\section{Development of Myobatrachus gouldii}

Clutch sizes of fertilised and ovarian eggs ranged from 9-38 (mean 25, $\mathrm{n}=5$; Roberts 1981). The mean diameter of 28 ovarian eggs from a female caught in February 1979 is $5.1 \mathrm{~mm}$, and mean diameters of 26, 38 and 9 ovarian eggs from three females collected 
in November and December 1979 are 5.0, 5.3 and $4.9 \mathrm{~mm}$, respectively (Roberts 1981). The mean capsule diameter of 23 live embryos from one clutch at early cell division collected in February 1979 is $7.4 \mathrm{~mm}( \pm 0.5 \mathrm{SD})$. The live embryos are creamy white, and the surface of the capsules are sticky to the touch, fairly tough and covered with fine sand. They soon become like firm, round balls to touch. Early cell division in live embryos at stage 1 is similar to that described for Heleioporus eyrei at Gosner stage 4 (Packer 1966) with four, dorsal micromeres and two perpendicular, incomplete cleavage furrows at the vegetal pole. Embryos at the earliest preserved stages available at stage 5 (T\&S) have small limb buds, but unlike $E$. coqui at this stage, the eyes are partially pigmented (see Discussion).

Stages 5, 6, 9, 10,11, 13 and 15 are described in Table 2, and illustrated in Figures 3 and 4.

\section{Hatchlings}

Hatching was not observed. Five fully formed froglets just prior to and just after hatching measured 8.9-10.8 $\mathrm{mm}$ (mean 10.1), were exact miniatures of the adult in form and pigmentation and began to burrow soon after hatching.

In summary, $A$. rotunda and $M$. gouldii share the following characteristics: large, unpigmented ova encapsulated with a thin outer layer (that becomes fairly tough) and an inner jelly layer, no external gills or adhesive organs, early limb bud development prior to any optic pigmentation, no spiracle and forelimbs covered by the operculum until at least stage 7 . Eyes develop pigment gradually from stage 5 and increase noticeably in diameter during stages $6-8$. The neural tube is initially raised above the large yolk (stages 4-5), gradually flattens and broadens from about stage 6 onward, then as vertebrae develop, the vertebral column appears as a broad, thickened ridge. The vent tube begins to develop from about stage 4 , the gut gradually develops from initial divisions in the yolk at stage 6 , into a thick intestinal coil by stage 9 , and a small internal flap develops inside each naris from about stage 9 .

The mouth begins as a small stomodaeal pit at stage 4 , then becomes a simple slit that gradually widens with jaw development and never develops the oral mouthparts of a tadpole. During stage 9, a small flexible conical structure (visible when the mouth is opened) begins to project upwards from the inside centre of the lower lip and inserts into a corresponding notch centred in the upper lip; this projection becomes more defined in subsequent stages and the inner margin of the notch deepens posteriorly. These structures remain in the adult and are also present in the Australian microhylids (Anstis unpublished observations). Frog-like features of the head develop from as early as stage 9 .

\section{DISCUSSION}

\section{Comparative development}

Although not all stages were available for the two species, an adequate comparative understanding of their development can be gained from the existing material, because in those stages where direct comparison was possible, similarities were quite evident and differences were minor. No pairs of adults for either species were observed in amplexus and the mode of fertilisation could not be determined, but as eggs are laid in sand, internal fertilisation could be advantageous. The relatively large size of the ova and the small clutch sizes are also characteristic of direct developing species (e.g., 2.0-10.0 mm and clutch sizes of 1-94; Thibaudeau and Altig 1999). Based on the similarity in early cell division noted here between $H$. eyrei and $M$. gouldii, it is likely that cleavage is holoblastic, but more live material needs to be studied to verify this. The tough external capsules may protect developing embryos but do not prevent desiccation in M. gouldii (Roberts 1981). Death by desiccation may be a result for embryos of both species if normal winter rains are delayed.

Arenophryne rotunda has a shorter tail with low fins and a narrower muscle and much narrower tail tip than M. gouldii. Myobatrachus gouldii has a long tail with more prominent fins that provide a greater degree of vascularisation, a broad muscle, broadly rounded tip and the tail is well advanced by stage 5 (Figure $3 \mathrm{~A}$, Table 3). Pigmentation is generally less dense in $A$. rotunda during stages 49. The forelimbs emerge through the epidermis during stage 7 for $A$. rotunda and about stage 10 for M. gouldii.

Arenophryne rotunda and $M$. gouldii have forward burrowing behaviour (Tyler et al. 1980; Main et al. 1959; Lindgren and Main 1961), and the minute flap in the narial canal which persists in adults, possibly prevents sand particles being lodged in the nostrils during burrowing.

\section{Hatching}

Hatching in these species has not been fully observed, but in $A$. rotunda, one embryo pushed a hind limb through the capsule wall at the onset of hatching. In a description of the hatching process of the microhylid Cophixalus darlingtoni from Papua New Guinea, Tyler (1976b) observed that prior to hatching, the embryo used only abrupt, outstretched movements of the arms and legs to split the capsule. From the one observation of the $A$. rotunda hatchling, it appears that the hatching process in $A$. rotunda, and probably $M$. gouldii, is similarly precipitated by abrupt movements of the limbs, since the outer layer of the jelly capsule is dry and tough and the embryos already have quite robust forelimbs. 
The turgidity of the egg jellies of direct developers would seem to require the use of an egg tooth during hatching, and embryos of species of Eleutherodactylus are known to poke at the inside of the egg capsule with the keratinised egg tooth on the upper lip (Townsend and Stewart, 1985; Duellman and Trueb, 1986). In $A$. rotunda and $M$. gouldii, however, there is no egg tooth, only the small, nonkeratinised conical projection described.

\section{Comparisons with Eleutherodactylus coqui}

The two Australian myobatrachids differ from $E$. coqui in that they deposit eggs in subterranean sites, they do not develop an egg tooth, the initial development of the forelimbs is internal prior to stage 7 or 10 (exposed from stage 4 in E. coqui), the tail is more advanced in development by stage 5 ( $M$. gouldii) and there are no external gills. Apart from the differences noted above and those in Table 3 , they have a generally similar developmental life history to $E$. coqui, but it has not been possible to adequately compare aspects of gut, mouth and eye development (choroid fissure), vitelline circulation and behaviour.

\section{Comparisons with other Australian myobatrachids and microhylids}

Arenophryne rotunda and Myobatrachus gouldii share key features typical of direct development as defined by Altig and Johnston (1989) including the lack of mouthparts and a spiracle. The absence of a spiracle and mouthparts are also typical of other Australian endotrophic guilds including Assa darlingtoni and Bryobatrachus nimbus (Anstis 2002). The paraviviparous genus Rheobatrachus and the nidicolous species of Geocrinia, however, have a vestigial spiracle and much reduced mouthparts, including a few very small lateral marginal papillae and nonkeratinized jaw ridges (Anstis unpublished observations; Watson and Martin 1973; Tyler and Davies 1983). Adhesive glands are absent in $A$. rotunda and $M$. gouldii and in Spicospina flammocaerulea from southwestern Australia, a species with aquatic development in which the hatchlings are fully supported within thick algae mats (Dziminski and Anstis 2004), negating the need for adhesive glands.

Exposed forelimb bud development throughout embryonic stages is found in the microhylid genus Cophixalus (Tyler 1976b; Anstis unpublished observations) and also in the earlier stages of Philoria, which has terrestrial, nidicolous larvae. In at least three species of Philoria ( $P$. sphagnicolus, $P$. kundagungan and $P$. loveridgei), all four limb buds are initially exposed from about Gosner stage 20, but the forelimbs are soon covered by the operculum and continue development internally during larval stages, breaking through the operculum at Gosner stage 42 (Anstis 1981; De Bavay 1993; Ingram and Corben 1975; Anstis 2002).

Further studies on the Australian direct developing genera are required to improve our understanding of their morphology, physiology and general biology, including mode of fertilisation, embryonic behaviour, life span and the hatching process, so that adequate future comparisons can be made with other direct developing genera.

\section{ACKNOWLEDGEMENTS}

The Western Australian Museum is gratefully acknowledged for the loan of the specimens studied. Field work and research was supported by the University of Western Australia. We thank the staff at the University of Western Australia for their assistance. K. Thumm and several reviewers offered helpful suggestions on the manuscript.

\section{REFERENCES}

Altig, R. and Johnston, G.F. (1989). Guilds of anuran larvae: relationships among developmental modes, morphologies, and habitats. Herpetological Monographs 3: 81-109.

Anstis, M. (1981). Breeding biology and range extension for the New South Wales frog Kyarranus sphagnicolus (Anura: Leptodactylidae). Australian Journal of Herpetology 1: 1-9.

Anstis, M. (2002). Tadpoles of south-eastern Australia: a guide with keys. Reed New Holland, Sydney, Australia.

De Bavay, J. M. (1993). The developmental stages of the sphagnum frog, Kyarranus sphagnicolus Moore (Anura: Myobatrachidae). Australian Journal of Zoology 41: 275-93.

Duellman, W.E. and Trueb, L. (1986). Biology of Amphibians. McGraw-Hill Book Company, New York.

Dziminski, M. A. and Anstis, M. (2004). Embryonic and larval development of the sunset frog, Spicospina flammocaerulea (Anura: Myobatrachidae), from southwestern Australia. Copeia 2004: 893-899.

Frost, D.R., Grant, T., Faivovich, J., Bain, R., Haas, A., Haddad, C.F.B., de Sá, R.O., Donnellan, S.C., Raxworthy, C.J., Wilkinson, M., Channing, A., Campbell, J.A., Blotto, B.L., Moler, P., Drewes, R.C., Nussbaum, R.A., Lynch, J.D., Green, D. and Wheeler, W.C. (2006). The amphibian tree of life. Bulletin of American Museum of Natural History. 297: 1-370.

Gitlin, D. 1944. The development of Eleutherodactylus portoricensis. Copeia 1944: 91-98.

Gosner, K. L. (1960). A simplified table for staging anuran embryos and larvae with notes on identification. Herpetologica 16: 183-190.

Ingram, G. J. and Corben, C.J. 1975. A new species of Kyarranus (Anura: Leptodactylidae) from Queensland, Australia. Memoirs of the Queensland Museum. 17: 335-339. 
Jameson, D. L. 1950. The development of Eleutherodactylus latrans. Copeia 1950: 44-46.

Lindgren, E., and Main, A.R. (1961). Natural history notes from Jigalong, IV: Frogs. West Australian Naturalist 7: 193-195.

Main, A. R., Littlejohn, M.J. and Lee, A.K. (1959). Ecology of Australian frogs, p. 396-411. In Biogeography and Ecology in Australia, eds A. Keast, R. L. Crocker and C. S. Christian. Junk: The Hague.

Maxson, L. R. and Roberts, J.D. (1985). An immunological analysis of the phylogenetic relationships between two enigmatic frogs, $M$. gouldii and $A$. rotunda. Journal of Zoology (London) 207: 289-300.

Packer, W. C. (1966). Embryonic and larval development of Heleioporus eyrei (Amphibia: Leptodactylidae). Copeia 1966: 92-97.

Read, K., Keogh, J.S., Scott, I.A.W., Roberts, J.D. and Doughty, P. (2001). Molecular phylogeny of the Australian frog genera Crinia and Geocrinia and allied taxa (Anura: Myobatrachidae). Molecular Phylogenetics and Evolution 21: 294-308.

Roberts, J. D. (1981). Terrestrial breeding in the Australian leptodactylid frog Myobatrachus gouldii (Gray). Australian Wildlife Research 8: 451-62.

Roberts, J. D. (1984). Terrestrial egg deposition and direct development in Arenophryne rotunda Tyler, a myobatrachid frog from coastal sand dunes at Shark Bay, W.A. Australian Wildlife Research 11: 191-200.

Thibaudeau, G., and Altig, R. (1999). Endotrophic Anurans, p. 170-188. In Tadpoles: the Biology of Anuran Larvae, eds R. W. McDiarmid and R. Altig. University of Chicago Press, Chicago.

Townsend, D. S. and Stewart, M.M. (1985). Direct development in Eleutherodactylus coqui (Anura: Leptodactylidae): a staging table. Copeia 1985: 423436.

Tyler, M. J. (1962). On the preservation of anuran tadpoles. Australian Journal of Science 25: 222.

Tyler, M. J. (1976a). A new genus and two new species of leptodactylid frogs from Western Australia. Records of the Western Australian Museum 4: 45-52.

Tyler, M. J. (1976b). Frogs. Australian Naturalist Library. Collins, Australia.

Tyler, M. J., Roberts, J.D. and Davies, M. (1980). Field observations on Arenophryne rotunda Tyler, a leptodactylid frog of coastal sandhills. Australian Wildlife Research 7: 295-304.

Tyler, M. J., Smith, L.A. and Johnstone, R.E. (2000). Frogs of Western Australia. Western Australian Museum, Perth.

Wake, M. H. 1978. The reproductive biology of Eleutherodactylus jasperi (Amphibia, Anura, Leptodactylidae), with comments on the evolution of live-bearing systems. Journal of Herpetology 12(2): 121-133.

Watson, G. F., and Martin, A. A. (1973). Life history, larval morphology and relationships of Australian leptodactylid frogs. Transactions of the Royal Society of South Australia 97: 33-45.

\section{APPENDIX 1}

Collection and preservation dates (day/month/ 1981), stage (Townsend and Stewart 1985), and embryo dimensions ( $\mathrm{mm}$, diameters to stage 9, snout-vent length for stage 15) of Arenophryne rotunda. WAM $=$ West Australian Museum. $N=1$ in each case, see footnote.

$\begin{array}{llllll}\text { Clutch } & \text { WAM } & \text { Coll. } & \text { Pres. } & \text { Stage } & \text { Dimensions } \\ 1 & \mathrm{R} 97056 & 1 / 4 & 1 / 4 & 1 & 5.0 \\ 2 & \mathrm{R} 97054 & 1 / 4 & 1 / 4 & 1 & 4.5 \times 4.4 \\ 4 & \mathrm{R} 97046 & 3 / 4 & 10 / 4 & 2 & 5.0 \\ 4 & \mathrm{R} 97047 & 3 / 4 & 16 / 4 & 3 & 5.0 \times 4.7 \\ 1 & \mathrm{R} 97057 & 1 / 4 & 10 / 4 & 4 & 5.2 \times 5.0 \\ 4 & \mathrm{R} 97048 & 3 / 4 & 24 / 4 & 6 & 5.0 \times 4.2 \\ 3 & \mathrm{R} 97049 & 1 / 4 & 16 / 4 & 6 & 5.1 \times 4.5 \\ 3 & \mathrm{R} 97050 & 1 / 4 & 24 / 4 & 7 & 4.8 \times 4.6 \\ 4 & \mathrm{R} 97052 & 1 / 4 & 15 / 5 & 7 & 5.7 \times 4.7 \\ 1 & \mathrm{R} 97059 & 1 / 4 & 24 / 4 & 9 & 5.6 \times 5.5 \\ 3 & \mathrm{R} 97053 & 1 / 4 & 22 / 5 & 15 & 6.6 \mathrm{SVL} \\ 1 & \mathrm{R} 97060 & 1 / 4 & 1 / 5 & 15 & 4.8 \mathrm{SVL}\end{array}$

${ }^{1}$ external egg diameter of one individual $=6.1 \mathrm{~mm}$.

\section{APPENDIX 2}

Collection and preservation dates, stage (Townsend and Stewart 1985), and embryo dimensions (mm, diameters to stage 10 , snout-vent length for stages 13-15) of Myobatrachus gouldii. WAM $=$ West Australian Museum. $\mathrm{N}=1$ in each case, except $\mathrm{R} 97037=4$, range in parenthesis.

$\begin{array}{llllll}\text { Clutch } & \text { WAM } & \text { Coll. } & \text { Pres. } & \text { Stage } & \text { Dimensions } \\ 1 & \text { R97036 } & 4 / 3 / 81 & 4 / 3 / 81 & 5 & 5.7 \times 5.6 \\ 1 & \text { R97036 } & 4 / 3 / 81 & 4 / 3 / 81 & 5 & 5.7 \times 5.7 \\ 1 & \text { R97037 } & 4 / 3 / 81 & 13 / 3 / 81 & 6 & 5.1 \times 5.5 \\ & & & & & (4.8-5.4 \times 5.2-5.8) \\ 1 & \text { R97038 } & 4 / 3 / 81 & 27 / 3 / 81 & 9 & 6.4 \times 6.2 \\ 1 & \text { R97040 } & 4 / 3 / 81 & 16 / 4 / 81 & 9 & 6.6 \times 6.4 \\ 1 & \text { R97039 } & 4 / 3 / 81 & 3 / 4 / 81 & 10 & 6.1 \times 5.8 \\ 2 & \text { R97041 } & 14 / 4 / 82 & 14 / 4 / 82 & 13 & 8.5 \text { SVL } \\ 3 & \text { R97042 } & 14 / 4 / 82 & 14 / 4 / 82 & 15 & 10.8 \text { SVL } \\ 3 & \text { R97043 } & 23 / 4 / 82 & 23 / 4 / 82 & 15 & 10.5 \text { SVL } \\ 5 & \text { R97044 } & 7 / 4 / 81 & 7 / 4 / 81 & 15 & 8.9 \text { SVL } \\ 5 & \text { R97044 } & 7 / 4 / 81 & 7 / 4 / 81 & 15 & 10.0 \text { SVL } \\ 4 & \text { R97945 } & 14 / 4 / 81 & 14 / 4 / 81 & 15 & 10.1 \text { SVL }\end{array}$

${ }^{1}$ Egg dimensions $=11.3 \times 10.8 \mathrm{~mm}$

${ }^{2}$ Egg dimensions $=11.3 \times 10.5 \mathrm{~mm}$ 